\title{
Legal Review on the Application of Acquiescence and Estopple in the Temple of Preah Vihear Case
}

\author{
Youpeng Kong ${ }^{1}$ \\ ${ }^{1}$ China Institute of Boundary and Ocean Studies, Wuhan University, Wuhan, China \\ Correspondence: Youpeng Kong, China Institute of Boundary and Ocean Studies, Wuhan University, Wuhan, \\ Hubei, China. E-mail: kypkun@163.com
}

Received: December 26, 2021

Accepted: January 20, 2022

Online Published: January 25, 2022

doi:10.20849/ajsss.v7i1.980

URL: https://doi.org/10.20849/ajsss.v7i1.980

\begin{abstract}
Acquiescence and estopple are regarded as two essential international principles in the judgement of the Case concerning the Temple of Preah Vihear. This is a legal review essay to make some remarks on the application of these two principles in the Temple of Preah Vihear Case combined with some judgments of the other Cases and the opinions of Judges or scholars, and to point out the rationality of the application of acquiescence and the controversies over the application of estoppel in this case.
\end{abstract}

Keywords: Temple of Preah Vihear Case, acquiescence, estopple, treaty interpretation

\section{Introduction}

The Temple of Preah Vihear Case is a dispute of territory sovereignty between Cambodia and Thailand over the region of the Temple of Preah Vihear. The Temple is located in borders of Cambodia and Thailand, standing on the Preah Vihear promontory, belonging to the eastern sector of the Dangrek range of mountains. The Treaty of 13 February 1904 concluded by the France, conducting the foreign relations of Cambodia and Siam prescribed that in the eastern sector of the Dangrek range, in which Preah Vihear was situated, the frontier was to follow the watershed line. The Temple of Preah Vihear is situated in Thailand in accordance with the watered line. Meanwhile, a Mixed Commission of delimitation established according to the Treaty of 1904 was responsible for delimiting the exact boundary, but it failed to make clear the boundary of area where the Temple is located. After the completion of the work of delimitation, the Siamese Government, which did not dispose of adequate technical means, had requested that French officers should map the frontier region. One of a series of maps (Hereinafter called Annex I Map) (Note 1) made by France based on the delimitation results of the Mixed Commission placed the Temple on the Cambodian side. Thailand had realized that the frontier line in that map didn't correspond with the watershed line of Dangrek range of mountains and had opportunities to raise objections to France or Cambodia. However, Thailand had never done that until 1958. After Cambodia received independence in 1953, Thailand dispatched armed force to occupy the Temple. With the failure to reach agreement about the territory dispute through negotiation and deliberation, Cambodia filed a lawsuit concerning the dispute of the Temple against Thailand to the International Court of Justice (Hereinafter called the Court).

The Court reached its conclusion by examining the treaty between the two sides and the conduct in subsequent decades. The silence of the Siamese government at the beginning of its acceptance of the map and for many years thereafter meant that Siam accepted the boundaries of the Annex I Map. Moreover, since Thailand enjoys the benefits of a stable boundary brought by the 1904 Treaty, it can no longer deny its acceptance of the boundary on the map of Annex I according to the estoppel principle. Finally, the Court held that the boundary lines in the Annex I map had been accepted by Thailand as an integral part of the border treaty from the perspective of treaty interpretation and that the Court had therefore upheld the validity of the Annex I map line for the disputed area without regard to whether the drawn boundary line actually corresponds to the true watershed line. For these reasons, the Court upheld Cambodia's claim to the Temple of Preah Vihear

\section{Rationality of the Application of Acquiescence in this Case}

The Annex I Map played a crucial role in the process of the deciding of the court. But the map cannot serve as a title of the acquisition of territory. Virtually, the map had never been approved by the Mixed Commission and had no binding character when the maps were first produced. But the fact that Siam kept silence to the maps 
constitutes acquiescence legally. The acquiescence of Siam to the Annex I Map made the map line represent the agreement of the Parties concerning the frontier line and have binding character. The Court considered that the acceptance of the Annex I Map cause it enter the interpretation of the Treaty. First, the essay will focus on the discussion of the issue of acquiescence or tacit recognition.

A very importance paragraph in the judgement of the Temple of Preah Vihear Case points out that "it is clear that the circumstances were such as called for some reaction, within a reasonable period, on the part of the Siamese authorities, if they wished to disagree with the map or had any serious question to raise in regard to it. They did not do so, either then or for many years, and thereby must be held to have acquiesced. Qzri tacet consentire videtur si loqui debuisset ac potuisset." (Note 2) Generally, when deciding the acquiescence, three requirements should be taken into consideration. First, the state knows or should know the claims of another State; Second, it should and can respond to defend its rights in the special circumstance; And third, it remains silent or fails to protest or put forward in a timely manner. If the above situation is met, the silence of the state is possible to be regarded as acquiescence.

\subsection{Whether Thailand Knows or Should Know the Annex I Map Line}

Knowing the claims of another State is a prerequisite for acquiescence. Johnson maintains, "acquiescence is often implied, in the interests of international order, in cases where it does not genuinely exist; but without knowledge there can be no acquiescence at all." (Note 3) If the state don't know or can't know the claim of another state, it is hard for the state to respond to it. It means that the competing claim of one state should be public to another state in order to get the legal effect of acquiescence. It is understandable that the other party has failed to respond and react if the party exercises the right of sovereignty over the disputed territory and intentionally conceals its actions. Generally, the act or claim concerning the disputed territory sovereignty is particularly sensitive to relevant states. If the other state conducted some activities that violate the territory sovereignty right of one state publicly, it would definitely give rise to the strong reaction of the state.

The Malaysia/Singapore Case indicates the confidential documents cannot be used as an evidence on the basis of which the State claims the territory sovereignty. In the Fisheries Case, the Court described the UK with terms "greatly interested in the fisheries in this area" and "a maritime Power traditionally concerned with the law of the sea and concerned particularly to defend the freedom of the seas." (Note 4) It made the Court have enough reasons to presume that the UK should know and could not ignore the claim of Norwegian system of delimitation. It seems that the Court tends to consider the State could know the competing claims of other States if its significant interest is involved or violated.

From the discussion above, it can be concluded that the State needn't respond to the confidential claims or activities. And in territorial disputes, knowledge is more likely to be presumed because, on the one hand, it is difficult to imagine that malicious occupation can be carried out in secret for a long time and unknown. On the other hand, territorial issues are generally highly sensitive, and States will pay special attention to the relevant acts and attitudes of other States, especially in the case of having territorial disputes with other States, to safeguard territorial sovereignty and national security.

Now turn to the Temple of Preah Vihear Case. The claim of Cambodia on the territory sovereignty over the Temple area was presented by a special way -- the frontier line on the Annex I Map. Siam contends that Siamese authorities were unaware of the error at the time when they received the map. However, this contest was not supported by the Court.

In contrast, some dissenting opinions question the conclusion of the Court about whether Siam could have realized the error of the map line. Judge Koo argued that "the Annex I map was drawn on the scale of 1: 200,000, which means that the distance of 500 meters on the ground lying between the alleged frontier line and the Temple area is represented on the map by a width of only 2.5 millimetres. And because the Temple is perched on the summit of the promontory of Preah Vihear, the mark indicating the Temple is buried in a tangle of contour lines in a small part of the map." (Note 5) It indicates that it is difficult to find the temple's mark on the map, without looking carefully.

In addition, Judge Quietana considered that "to take a decision in this case on the basis of assumptions or hypotheses in order to resolve the question at issue would not seem very consistent with the rules of judicial settlement." (Note 6) It seems that these judges could give some reasonable interpretation why Siam didn't find the alleged error of the map line at the time when Siam accepted the map. However, when putting the issue in the circumstance where the Parties concluded a treaty and established a Mixed Commission to resolve the boundary question, the map's meaning is significant and sensitive. Siam is expected to be prudent and diligent to inspect the maps in the circumstance, even extremely small place, because Thailand is highly interested Party to the, 
though the maps hadn't been approved by the Mixed Commission had no binding character at the beginning. That is to say, it can be presumed reasonably that Siamese authority should inspect the maps diligently and could find the alleged error of the Annex I map line.

\subsection{Whether Thailand Should and Can Protest Against the Annex I Map Line}

Not all silence constitutes acquiescence, but it must first be clear in what circumstances there should be a response. Judge Quietana noted in the Dissenting Opinion "silence has consequences in law only if the party concerned is under an obligation to make its voice heard in response to a given fact or situation. It would thus have been necessary to show that Thailand was under such an obligation in respect of an act devoid in itself of legal significance." (Note 7)

In territorial disputes, in the face of clear claims of sovereignty over the disputed territory by other States, whatever their form, including declarations or acts, it is inconceivable that a State which wishes to preserve and maintain its territorial sovereignty would remain silent at this time without protest. The silence may well constitute acquiescence to claims of other States.

In the Temple of Preah Vihear Case, most of the evidences are debated surrounding the map. The origin of the divergence of the Parties on the map probably is due to the careless and negligence of the Siamese officers. The defence of Thailand is mostly based on that the Siamese authority believed the map line coincided the watershed line and the Temple was always under her own sovereignty. Once the Court presumed that Siam could know the exact location of the Temple on the map and should raise objection to France, it is difficult for Thailand to contest she didn't recognize the map line by acquiescence.

Apart from the map evidence, the visit to the Temple by Prince Damrong was also important. When in 1930, Prince Damrong, on a visit to the Temple, was officially received there by the French Resident for the adjoining Cambodian province, with the France flag flying, Siam failed to react. The Court noted that the flying France flag demanded a reaction. The Court presumed the silence of Prince Damrong as a acquiescence over Preah Vihear. Judge Koo expressed his dissenting opinions on this visit. First, "The Prince then was no longer Minister of the Interior. The Prince, in his reply, said that "he had come to see the Temple and had nothing to do with politics." (Note 8) Second, "the display of his national flag by a foreign official, even by a private Occidental, was not an uncommon sight in an Asiatic country during that epoch. It may or may not have displeased the Prince." (Note 9) Third, the daughter of Prince Damrong explained the reason of inaction as follows: "It was generally known at the time that we only give the French an excuse to seize more territory by protesting." (Note 10) Furthermore, Judge Koo noted that "in view of the history of the relations between Siam and French at the time and earlier during the preceding decades, the Princess's explanation seems natural and reasonable. It was a situation not peculiar to Siam. It was, generally speaking, the common experience of most Asiatic States in their intercourse with the Occidental Powers during this period of colonial expansion." (Note 11)

Judge Koo found out some favorable interpretation for the Siam' silence from the respective of the special history background. Following the analysis line, it can be said that Thailand "could not" respond to France. In addition, G.M. Kelly drew attention to Siam's administrative difficulties in the struggle for political and economic survival in which the standards of a wide doctrine of preclusion cannot, according to him, be used. (Note 12) Thailand's insistence on protest could have adverse consequences because of the capacity inequality between Siam and France. Although Judge Koo found some favorable explanations for Siam's silence from the perspective of special historical background, they were still not adopted by the judgment of this case.

\subsection{Thailand Failed to Raise Objections in Time}

Obviously, Thailand didn't show any opposite opinion to the map line. But that is because Thailand never thought that the map line didn't coincide the watershed line and she should do some reaction to the map. Therefore, in the present case, the first two elements are more important in the assertion of acquiescence. In the view of the essay, the mistake of not finding the error of the map line is the core cause of the troublesome.

In fact, Thailand maybe never thought that she had acquiesced the map line. But regretfully, according to the international rule, it is still reasonable for the Court to regard the inaction of Siam as acquiescence. And Thailand surely should pay the price for her mistake, but the acquiescence cannot amount to a title of the acquisition of the territory. Even acquiescence cannot be combined with estoppel to give a final and binding effect to Thailand in the present case, which will be further discussed below. 


\section{Controversies Over the Application of Estoppel Principle in this Case}

\subsection{The Elements of Estoppel in International Law}

It is often analyzed as that the Court decided the Temple belonged to Cambodia on the basis of acquiescence and estoppel. However, the application of estoppel or the principle of preclusion is very debatable. In the Judgment, the Court stated that "The Court would consider, in the light of the subsequent course of events, that Thailand is now precluded by her conduct from asserting that she did not accept it. She has, for fifty years, enjoyed such benefits as the Treaty of 1904 conferred on her, if only the benefit of a stable frontier." (Note 13) It can be seen that the Court applied the principle of preclusion and held that the Thailand benefits from the stable frontier, which cause much controversial. While acquiescence may result in the application of legally binding estoppel, not all acquiescence has such legal effect. "On the level of academic discourse, recent articles have tried to re-evaluate the ICJ ruling on the basis of an analysis of the terms acquiescence and estoppel, leading to the suggestion that these terms are open to misuse." (Note 14)

Now let us have a look at the statement about the elements of estoppel in the judgment by ICJ. The Court concluded that "Further to this jurisprudence, estoppel may be invoked where (a) a State has made clear and consistent representations, by word, conduct, or silence; (b) such representations were made through an agent authorized to speak for the State with respect to the matter in question; (c) the State invoking estoppel was induced by such representations to act to its detriment, to suffer a prejudice, or to convey a benefit upon the representing State; and (d) such reliance was legitimate, as the representation was one on which that State was entitled to rely." (Note 15) In the four elements, (c) matters most, which is most easily neglected in the application.

As Judge Fitzmaurice analyzed, "The essential condition of the operation of the rule of preclusion or estoppel, as strictly to be understood, is that the party invoking the rule must have 'relied upon' the statements or conduct of the other party, either to its own detriment or to the other' s advantage." (Note 16) In many cases, the State intending to acquire rights by estoppel lose its interest, whereas the harm is borne by the other party. In the absence of a change of the position of the parties, the effect of the expression is to be used as evidence, to weaken the party's claim as a result of inconsistent practice, and not as a binding estoppel.

\subsection{The Dissenting Opinions on the Application of Estoppel}

Following the analysis above, lots of objection about the application of estoppel in the present case arose. First, Judge Koo in his Dissenting Opinion discerned that "Thailand has not made a statement at any time indicating her acceptance or recognition of the frontier line marked on the Annex I map. There is no evidence to show that France, as Cambodia's protecting State, ever relied on Thailand's silence to her own detriment." (Note 17) Furthermore, Judge Koo also raised some queries about the "benefit" gained by Thailand.

In addition, Judge Percy opposed the application of estoppel from the respective of the burden of proof. He argued that the burden of proof lies upon Cambodia. Cambodia claimed the principle of estoppel during the oral proceeding. Therefore, the burden of proof lied with Cambodia but she never put forward evidence to prove the detriment she suffered due to the reliance to Thailand' s conduct.

From the dissenting opinion above, the application of estoppel in the Temple of Preah Vihear Case is still open to discussion. Meanwhile, there are also some warning of not misuse the principle. Judge Fitzmaurice pointed out that "However, in those cases where it can be shown that a party has, by conduct or otherwise, undertaken, or become bound by, an obligation, it is strictly not necessary or appropriate to invoke any rule of preclusion or estoppel, although the language of that rule is, in practice, often employed to describe the situation. " (Note 18)

In author's opinion, the Court didn't determine the sovereignty of Preah Vihear Temple only by application of estoppel. The Court invokes estoppel just to prevent Thailand from negating Annex I map or boundary line and strengthen the effectiveness of the treaty and Annex I map. It seems debatable whether the requirements for the application of estoppel in this case are reached, because the estoppel requires the relying party to be damaged by the other party's behaviors or claims. On the contrary, Thailand's behavior is to damage its own interests and benefit the other party. The reliability of France or Cambodia on this behavior does not meet the requirements of the principle of estoppel.

\section{Conclusion}

Based on the discussion above, in the view of this article, it is comparatively compelling to consider the inaction of Siam to the boundary line on the Annex I Map as acquiescence. Sometimes the acquiescence maybe cause the application of estoppel. However, the acquiescence doesn't necessarily lead to the effect of the estoppel. The State intending to invoke estoppel to claim rights must have "relied upon" the statements or conduct of the other 
party, either to its own detriment or to the other's advantage. This element is very essential. In the present case, Cambodia didn't submit the enough evidence to prove her detriment due to the reliance to the recognition. Therefore, it seems debatable whether the elements of estoppel are reached in this case.

In territorial disputes, the principle of peaceful and continuous display of territorial sovereignty is often used. In this case, the Court did not determine the sovereignty of the temple from the principle of peaceful and continuous display of territorial sovereignty. On the one hand, treaties are the primary basis for the settlement of territorial disputes by International Court of justice or arbitral tribunals. On the other hand, Cambodia and Thailand may not have enough evidence to prove the peaceful and continuous display of sovereignty in the Preah Vihear Temple area after 1908. Therefore, it is likely that this principle will not help the Court to make a sufficiently convincing final judgment. In addition, the 1904 Treaty was concluded to deal with the boundary between the two sides. The two sides were in a state of border instability before 1904, and the 1904 Treaty reached a clear and lasting solution to the border issue. From the perspective of treaty interpretation, the Court analyzed the Annex I map and the treaty as a whole. Combined with the purpose of the treaty, subsequent treaties and subsequent practice, the Annex I map line is superior to the provisions of the 1904 Treaty, which represents the agreement and binding force between the two sides on the boundary line.

\section{References}

Buss, A. (2004). The Preah Vihear Case and Regional Customary Law. 9 Chinese JIL, 111-126.

Chagos Marine Protected Area Arbitration (Maurice v. United Kingdom). Award of 1 March 2015.

Johnson, D. H. N. (1950). Acquisitive Prescription in International Law. 27 British Year Book of International Law, 332.

Kelly, G. M. (1963). The Temple Case in Historical Perspective. 39 British YBIL, 462-472.

Sovereignty over Pedra Branca/Pulau Batu Puteh, Middle Rocks and South Ledge (Malaysia/Singapore). Judgment, I. C. J. Reports2008. 12.

The Case concerning the Temple of Preah Vihear (Cambodia v. Thailand). (1962). Merit, Judgment, I. C. J. Reports. 6.

The Fisheries Case (United Kingdom v. Norway). (1951). Judgment, I. C. J. Reports1951. 116.

The Island of Palmas Case (the United States of America v. the Netherlands). 4 April 1928.

\section{Notes}

Note 1. Because the map was copied in Annex I of Cambodia's pleading to the Court.

Note 2. The Case concerning the Temple of Preah Vihear( Cambodia v. Thailand), Merit, Judgment, I C J, Reports 1962, p. 23.

Note 3. D.H.N. Johnson, Acquisitive Prescription in International Law, 27 British Year Book of International Law (1950), p. 347.

Note 4. The Fisheries Case (United Kingdom v. Norway), ICJ Reports 1951, pp.26-27.

Note 5. Dissenting Opinion of Judge Koo, para.19.

Note 6. Dissenting Opinion of Judge Quietana, p.65.

Note 7. Dissenting Opinion of Judge Quietana, p.68.

Note 8. Dissenting Opinion of Judge Koo, para.32.

Note 9. Ibid., para. 33.

Note 10. Ibid., para. 34 .

Note 11. Ibid.

Note 12. G.M. Kelly, The Temple Case in Historical Perspective, 39 British YBIL (1963), pp. 462-472.

Note 13. The Case concerning the Temple of Preah Vihear( Cambodia v. Thailand), Merit, Judgment, ICJ Reports 1962, p. 28. 
Note 14. Andreas Buss, The Preah Vihear Case and Regional Customary Law, 9 Chinese JIL (2004), pp. 111126.

Note 15. Chagos Marine Protected Area Arbitration (Maurice v. United Kingdom), Award of 1 March 2015. p.174.

Note 16. Seperate Opinion of Judge Fitzmaurice, p.61.

Note 17. Dissenting Opinion of Judge Koo, para.47.

Note 18. Seperate Opinion of Judge Fitzmaurice, p.63.

\section{Copyrights}

Copyright for this article is retained by the author(s), with first publication rights granted to the journal.

This is an open-access article distributed under the terms and conditions of the Creative Commons Attribution license (http://creativecommons.org/licenses/by/4.0/). 